\title{
Effect of some medicinal herbs and spices from Enugu and Kaduna States, Nigeria, on in-vitro rumen fermentation and methanogenesis
}

*Iyere, M. A ${ }^{1}$., **Bamikole, M. A ${ }^{1}$., Ikhatua U. J ${ }^{1}$, Babayemi, O. J. ${ }^{2}$ and Egigba, G. S . I. Department of Animal Science, University of Benin, Benin City, Nigeria and

${ }^{2}$ Department of Animal Science, University of Ibadan, Ibadan, Nigeria

Abstract

Corresponding authors:**bankymao@uniben.edu;*mabuyere@gmail.com

A study was carried out to determine the effect of medicinal plants from Enugu (En) and Kaduna (Kd) States on in-vitro rumen fermentation and methanogenesis. Twelve medicinal plants comprising herbs and spices were collected from En and Kd States, respectively. The chemical composition and cell wall component (NDF, ADF and hemicellulose) of the plants were determined. The samples were evaluated in an in-vitro study at an inclusion level of 10 $\mathrm{mg} / 200 \mathrm{mg}$ substrate. The experiment was laid out in a factorial arrangement and executed as a randomized complete block design with incubation done in batches. At the completion of the 24-hour incubation period, total gas volume (GV), dry matter digestibility (DMD), fermentation efficiency ( $F E)$ and $\mathrm{CH}_{4}$ were determined while organic matter digestibility (OMD), short chain fatty acids (SCFA) and metabolisable energy (ME) were estimated from established equations. The chemical composition indicated range values of 72.82 (Allium sativum, En) - 95.73\% (Aloe barbadense, Kd) for DM, 7.01 (Aframomum melegueta, En) 30.59\% (Allium sativum, En) for CP, 8.94 (Allium sativum, Kd) - 81.41\% (Cymbopogon citratus, En) for NDF, 3.58 (Allium sativum, En) - 63.64\% (Xylopia aethiopica, En) for ADF, 1.79 (Allium cepa, Kd) - $48.77 \%$ (Aframomum melegueta, En) for hemicellulose, 2.64 (Aframomum melegueta, En) - 22.51\% (Ageratum conyzoides, Kd) and 77.49 (Ageratum conyzoides, $\mathrm{Kd}$ ) - 97.36\% (Aframomum melegueta, En) for ash and OM, respectively. The effect of location on chemical composition varied among the plant types with significantly higher $(P<0.05)$ levels of $C P$ in most of the $\mathrm{Kd}$ plants. The range for $\mathrm{GV}, \mathrm{DMD}, \mathrm{CH}_{4}$ percentage, $\mathrm{CH}_{4}$ reduction, $\mathrm{FE}$, OMD, SCFA and ME were 85.00 (Ageratum conyzoides, $\mathrm{Kd}$ ) - $149.49 \mathrm{~mL} / \mathrm{g}$ DM (Aloe barbadense, Kd), 525.50 (Sida acuta, Kd) - $764.50 \mathrm{~g} / \mathrm{Kg}$ DM (Aframomum melegueta, En), 45.75 (Allium sativum, En) - 72.59\% (Aframomum melegueta, Kd), 2.36 (Allium cepa, Kd) - 32.86\% (Zingiber officinale, Kd), 4.23 (Sida acuta, Kd) - 8.12 (Ageratum conyzoides, Kd), 45.83 (Ageratum conyzoides, Kd) - 57.18\% (Cymbopogon citratus, Enugu; Aloe barbadense, Kd), 0.35 (Ageratum conyzoides, $\mathrm{Kd}$ ) - $0.66 \mathrm{mmol} / 200 \mathrm{mg}$ DM (Cymbopogon citratus, En) and 5.18 (Ageratum conyzoides, $\mathrm{Kd}$ ) - $6.93 \mathrm{MJ} / \mathrm{Kg} \mathrm{DM}$ (Cymbopogon citratus, En; Aloe barbadense, $K d$ ) respectively. Allium sativum bulbs, Zingiber officinale rhizomes, Cymbopogon citratus and Sida acuta (both locations) reduced $\mathrm{CH}_{4}$ production without adversely affecting the desired fermentation parameters indicating that the medicinal plants have methane reducing potential.

Keywords: Medicinal herbs, spices, in-vitro, rumen fermentation and methanogenesis

\section{Introduction}

Methane is one of the greenhouse gases linked to climate change, which is adversely affecting agricultural production as well as human lives due to the occurrence of natural disasters across the planet. The Intergovernmental panel on Climate Change (IPCC, 2007) predicts that by 2010 the temperature of the earth's atmosphere may have risen by $1.8-3.9^{\circ} \mathrm{C}$. FAO (2006) reports that a less than $1^{\circ} \mathrm{C}$ increase in the earth's atmospheric temperature over the last century has resulted in floods, forest fires and storms across the globe. Methane accounts for about $14 \%$ of human induced GHG production (Forster et al., 2007) and a 


\section{Effect of some medicinal herbs and spices from Enugu and Kaduna States, Nigeria}

$6-10 \%$ loss of gross energy intake via rumen fermentation (Eckard et al., 2010). In Nigeria it is estimated that ruminant livestock have a methane output of 59 $\mathrm{kg} /$ animal/year (FAO, 2010). With global population increasing at an annual rate of $1.3 \%$ (UNDESA, 2013) there is expected to be a corresponding increase in the level of agricultural production to meet their nutritional requirements. Consequently, livestock numbers are also expected to increase thus resulting in higher methane output from ruminant livestock except proactive steps are taken to increase the efficiency of rumen fermentation by reducing losses to methane production. Although several options have been explored over the years to address this emerging challenge there is now a preference for strategies that are safe for humans and livestock. Indigenous medicinal plants and spices which are often underutilized have prospects in this regard due to their content of bioactive compounds such as essential oils, tannins, saponins, flavonoids and alkaloids (Adu et al., 2013; Belewu et al., 2009; Doherty et al., 2010). These bioactive compounds have been reported to have antimicrobial activity (Belewu et al., 2009; Garba and Okeniyi, 2012; Uzeh and Oguntosin, 2013). It is therefore pertinent to access the level to which these medicinal plants can reduce methane production in the rumen as well as influence other fermentation parameters. Thus this study was conducted to evaluate the effect of some herbs and spices from Enugu and Kaduna States of Nigeria on invitro methanogenesis and fermentation parameters.

\section{Materials and methods}

\section{Sample collection, identification and preparation}

Medicinal plants and spices in Enugu and Kaduna States were catalogued and thereafter collected using purposeful sampling technique. Identification was done using ethnobotanical in literature. Local residents in both locations also assisted with the identification. The samples collected were classified as herbs and spices. The samples were air dried, milled and stored in air tight plastic containers prior to the determination of chemical composition and the in-vitro fermentation study.

\section{Substrate preparation}

The substrate $(\mathrm{CP}=11.80 ; \mathrm{OM}=83.59$; $\mathrm{NDF}=71.87 ; \mathrm{ADF}=34.82 ; \mathrm{CF}=19.92)$ comprised 30\% legume hay (Centrosema molle), 30\% grass hay (Panicum maximum) and $40 \%$ concentrate.

\section{Sample/substrate mixture}

$200 \mathrm{mg}$ of the substrate with $10 \%$ inclusion of the medicinal plant and spices respectively was weighed into previously numbered and weighed incubation bags which were then sealed and inserted into numbered $100 \mathrm{~mL}$ plastic syringes The 100 $\mathrm{ml}$ syringes were used in line with the protocol of Fievez et al. (2005).

Rumen liquor collection and buffer preparation

Rumen liquor was collected from six West African dwarf goats at the University of Benin Teaching and Research farm. The goats were confined and fed concentrate alongside Guinea grass (Panicum maximum) and served water ad-libitum. The liquor was collected early in the morning prior to feeding via stomach tube into a pre-warmed thermos flask. The liquor was strained through four layers of cheese cloth and mixed with the buffer solution in a ratio of 1:2. (Tilley and Terry, 1963; Menke et al., 1979) This mixture (inoculum) was dispensed into beakers which were placed in a water bath maintained at $39^{\circ} \mathrm{C}$ and flushed with $\mathrm{CO}_{2}$ to provide anaerobic conditions and keep the microorganisms alive.

In-vitro fermentation of samples

$30 \mathrm{~mL}$ of the inoculum was introduced into 


\section{Iyere, Bamikole, Ikhatua, Babayemi and Egigba}

each of the syringes containing the incubation bags. The syringes containing only inoculum served as the blank while those with bags containing only the substrate served as control. The volume of gas produced was read at six hour intervals for the 24 hour incubation period. Upon completion of the incubation period the syringes were prepared for methane determination. Methane production at the end of the incubation period was determined by injecting $4 \mathrm{~mL}$ of $40 \%$ sodium hydroxide $(\mathrm{NaOH})$ into each incubation syringe with agitation. The volume of gas after the movement of plunger ceased was recorded as the methane produced. The incubation bags were removed from the syringes, washed under running tap water and thereafter oven dried to constant weight to determine the dry matter digestibility (DMD). Metabolisable energy (ME), organic matter digestibility (OMD \%) and short chain fatty acid (SCFA) were estimated with established equations. The former were established with the equations of Menke and Steingass (1988) while the latter was with that formulated by Getachew et al. (1999).

\section{Chemical analysis}

Organic matter, crude protein, crude fiber and ash content of the substrate, spices and herbs were determined using the official procedure of AOAC (2000) while the Van Soest et al. (1991) method was used to determine the cell wall components i.e. acid detergent fiber (ADF), neutral detergent fiber (NDF) and hemicellulose.

\section{Data analysis}

Data collected were analyzed using ANOVA in a completely randomized design, following the procedure of SAS (2014). Separation of significant differences between the means was done using Duncan New Multiple Range Test of the SAS (2014) software.

\section{Results \\ Chemical composition of Panicum maximum used for the study}

Table 1 shows the chemical composition of the Panicum maximum fed to the WAD goats used in this study prior to rumen liquor collection. The DM, CP, NDF, ADF and HEM were 29.05, 7.71, 59.00, 37.00 and $22.00 \%$ respectively.

\section{Proximate composition of concentrate used for the study}

The DM, CP, CF, EE, ash and NFE respectively of the concentrate were $91.40,15.82,4.41,7.51,6.34$ and $57.32 \%$ as shown in Table 1.

\section{Chemical composition of herbs and spices used for the study}

The chemical composition of the herbs and spices in the present study is presented in Tables 2 and 3. The DM, CP, NDF, ADF, hemicellulose, ash and OM among the samples ranged from 72.82 (Allium sativum, En) - 95.73\% (Aloe barbadense, $\mathrm{Kd}$ ), 7.01 (Aframomum melegueta, En) 30.59\% (Allium sativum, En), 8.94 (Allium sativum, Kd) - 81.41\% (Cymbopogon citratus, En), 3.58 (Allium sativum, En) 63.64\% (Xylopia aethiopica, En), 1.79 (Allium cepa, Kd) - 48.77 \% (Aframomum melegueta, En), 2.64 (Aframomum melegueta, En) - 22.51\% (Ageratum conyzoides, Kd) and 77.49 (Ageratum conyzoides, Kd) - 97.36\% (Aframomum melegueta, En) respectively.

Effect of spices on in-vitro gas production and fermentation parameters

The GV, OMD, SCFA, FE and ME values obtained for the spices in this study as presented in Table 4 were similar to those obtained for the control indicating that there was no significant effect of the spice treatments. There were varying responses in the DMD due to the spice treatments. There were no significant differences among the Enugu spices while for Kaduna spices Aframomum melegueta significantly increased the DMD. Although there was a 


\section{Effect of some medicinal herbs and spices from Enugu and Kaduna States, Nigeria}

significant increase in $\mathrm{CH}_{4}$ production (7.99 \%) by Aframomum melegueta (Kaduna), non-significant $\mathrm{CH}_{4}$ reduction was observed in any of the spice treatments. Effect of herbs on in-vitro gas production and fermentation parameters

There were no significant differences between the herbs for in-vitro gas production and other fermentation characteristics as shown in Table 5. All the herbs reduced $\mathrm{CH} 4$ production to varied levels except Ageratum conyzoides (Enugu) and Tridax procumbens (Enugu).

Table 1: Chemical composition (g/100 g DM) of Panicum maximum and concentrate fed to WAD goats used for the study

\begin{tabular}{lcc}
\hline Composition & Panicum maximum & Concentrate \\
\hline Dry Matter & 29.05 & 91.40 \\
Crude Protein & 7.71 & 15.82 \\
Crude fibre & $\mathrm{ND}$ & 4.41 \\
Ether extract & 5.00 & 7.51 \\
Ash & 9.00 & 6.34 \\
Nitrogen free extract & $\mathrm{ND}$ & 57.32 \\
Neutral detergent fibre & 59.0 & $\mathrm{ND}$ \\
Acid detergent fibre & 37.0 & $\mathrm{ND}$ \\
Hemicellulose & 22.0 & $\mathrm{ND}$ \\
\hline
\end{tabular}

\section{Discussion}

The values for the chemical components of Panicum maximum are comparable with the range of 26.00 - 38.49, $5.20-9.36,40.30-$ $70.54,26.20-39.14$ and $14.10-22.00 \%$ for DM, CP, NDF, ADF and HEM respectively reported by several authors (Bamikole and Babayemi, 2004; Ajayi and Babayemi, 2008; Odedire and Babayemi, 2008; Babayemi, 2009). The CP content met the critical limit of $7 \%$ recommended by ARC (1980) for tropical livestock for proper functioning of the rumen below which there will be a decline in performance. Norton (1994) however suggested a minimum $\mathrm{CP}$ of $8 \%$ as the limit for optimal ruminal activity. The digestibility of the grass due to its NDF content is likely to be adversely affected as it has been reported (McDonald et al., 1995; Gillespie, 1998) that NDF is inversely related to plant digestibility. The $\mathrm{CP}, \mathrm{CF}$, EE, Ash and NFE respectively of the concentrate fed in this study are within the range of 13.5-16.80, 3.40-6.00, $6.60-8.60$, $4.80-6.40$ and $56.50-62.40 \%$ reported by Omajasola and Kayode (2015). The CP of the concentrate was higher than the minimum protein requirement of $10-12 \%$ recommended by ARC (1985) for ruminants. This indicates that the concentrate could aid in ameliorating dietary protein deficiency in a grass concentrate mixture for ruminant livestock. The CP content for majority of the herbs in this study were within the range of 8.90-24.90\% reported for herbs (Ahamefule et al., 2006; Sultan et al., 2009; Agunbiade et al., 2012; Midau et al., 2015). However, the values reported for Ageratum conyzoides (Kaduna) were higher than what was reported (15.67\%) by Agunbiade et al. (2012). The values for Sida acuta and Tridax procumbens (Kaduna) were also higher than those reported $(20.65 \%, 17.80$ $\%$ ) by Ahamefule et al. (2006). The NDF content of the herbs except Aloe barbadense (Kaduna) and Cymbopogon citratus (Enugu) were within the range (34.50 $75.00 \%$ ) reported (Ahamefule et al., 2006) for herbs. The ADF values were comparable with what was reported (32.40-57.40\%) by Ahamefule et al. (2006) except for Aloe barbadense (Kaduna) and Sida acuta. Most of the herbs had hemicellulose values which were lower than what was reported in literature (Sultan et al., 2009). The ash content was comparable to those reported by Ahamefule et al. (2006) and Midau et al. (2015). 


\section{Iyere, Bamikole, Ikhatua, Babayemi and Egigba}

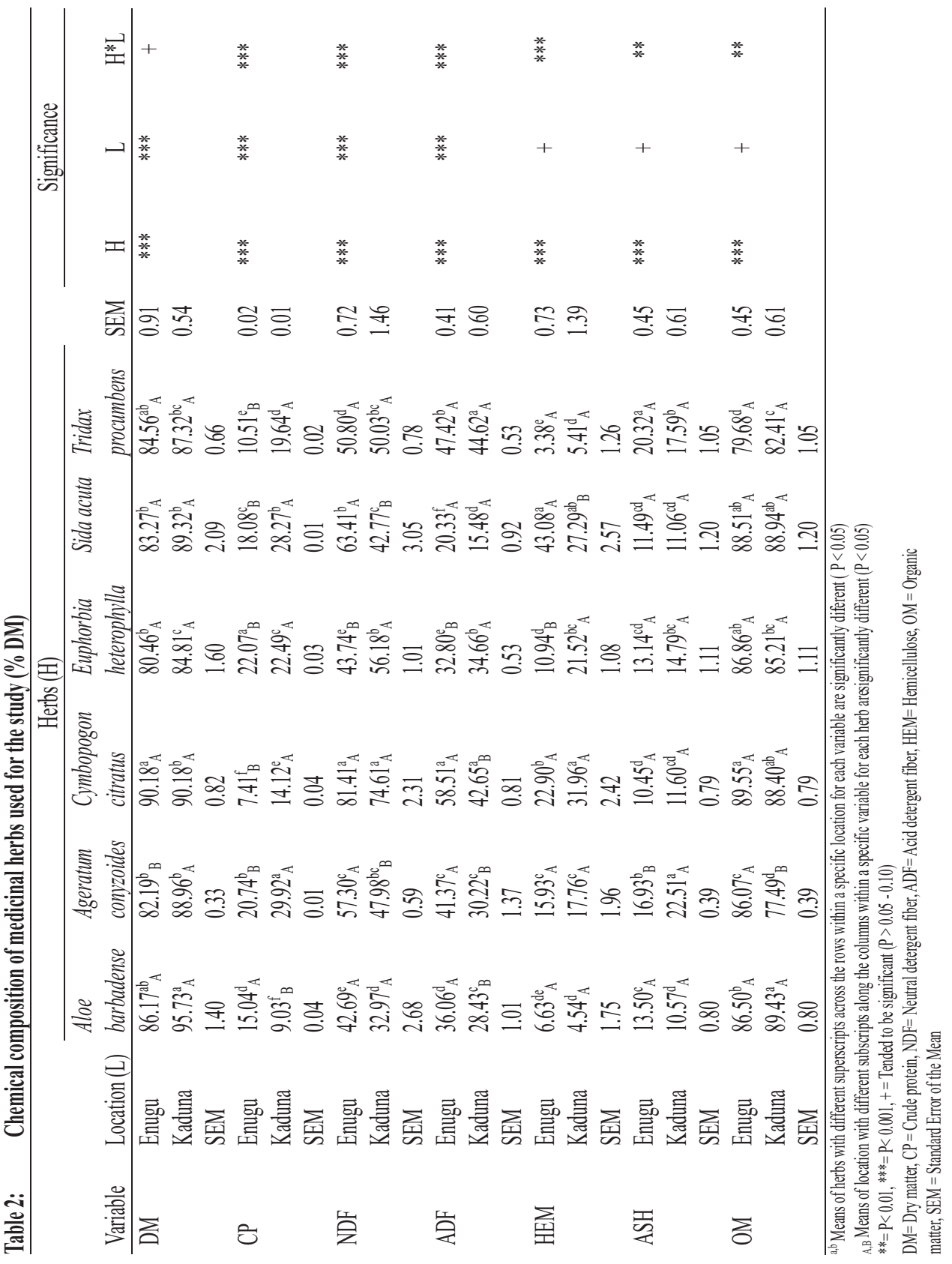




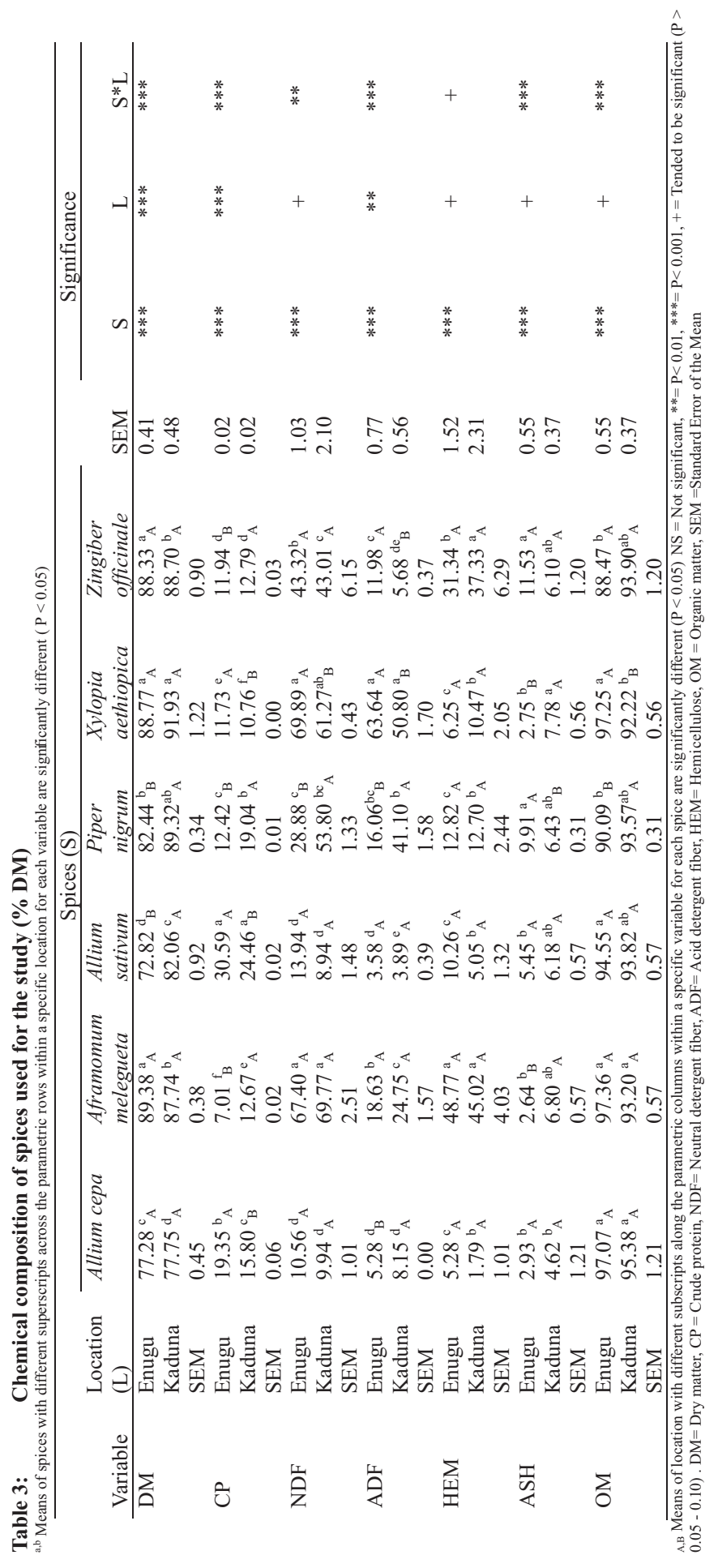




\section{Iyere, Bamikole, Ikhatua, Babayemi and Egigba}

Table 4: Effect of spices and location on in-vitro methanogenesis and fermentation parameters

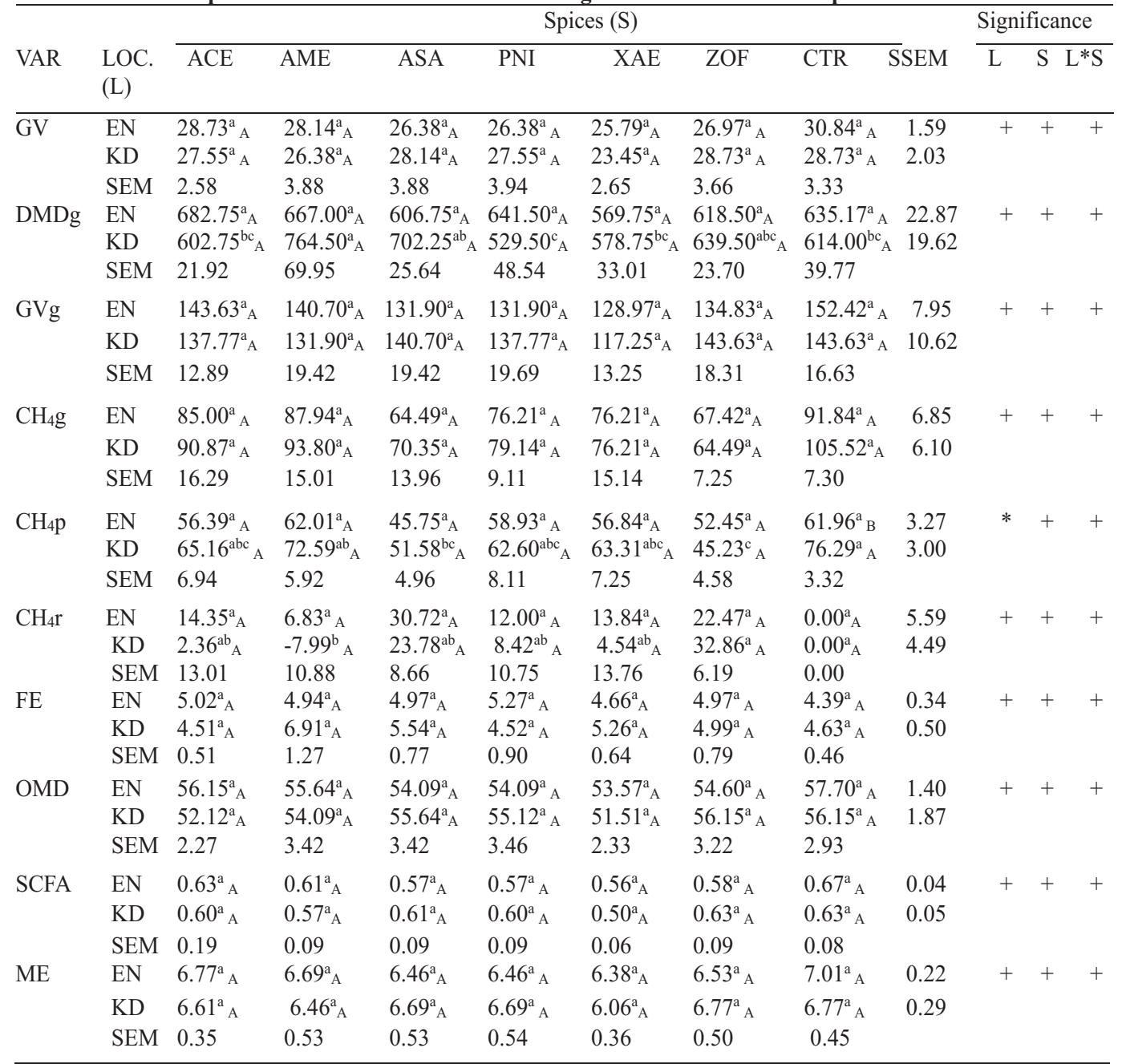

${ }_{\mathrm{a}, \mathrm{b}}$ Means of spices with different superscripts across the parametric rows within specific locations are significantly different $(\mathrm{P}<0.05)$

A,B Means of location with different subscripts along the parametric columns within individual spices are significantly different $(\mathrm{P}<0.05)$

$*=\mathrm{P}<0.05,+=$ Tended to be significant $(\mathrm{P}>0.05-0.10)$

$\mathrm{ACE}=$ Allium cepa, $\mathrm{AME}=$ Aframomum melegueta, $\mathrm{ASA}=$ Allium sativum, $\mathrm{PNI}=$ Piper nigrum, $\mathrm{XAE}=$ Xylopia aethiopica, $\mathrm{ZOF}=$ Zingiber officinale, $\mathrm{CTR}=\mathrm{Control}, \mathrm{GV}=\mathrm{Gas}$ volume $(\mathrm{mL} / 200 \mathrm{mg} \mathrm{DM}), \mathrm{DMDg}=$ Dry matter digestibility $(\mathrm{g} / \mathrm{Kg} \mathrm{DM}), \mathrm{GVg}=\mathrm{Gas}$ volume $(\mathrm{mL} / \mathrm{g} \mathrm{DM}), \mathrm{Cl}=\mathrm{g}=\mathrm{Methane}$ volume $(\mathrm{mL} / \mathrm{g} \mathrm{DM}), \mathrm{CH}_{4} \mathrm{p}=$ Methane $(\%), \mathrm{CH}_{4} \mathrm{r}=$ Methane reduction $(\%), \mathrm{FE}=$ Fermentation efficiency, OMD=Organic matter digestibility $(\%)$, SCFA = Short chain fatty acid $(\mathrm{mmol} / 200 \mathrm{mg} \mathrm{DM}), \mathrm{ME}=$ Metabolisable energy $(\mathrm{MJ} / \mathrm{Kg} \mathrm{DM}), \mathrm{SEM}=$ Standard Error of the Mean, VAR $=$ Variable, $\mathrm{LOC}=\mathrm{Location}$

Alluim sativum was the only spice which had CP values which was higher than the range $(7.4-22.30 \%)$ reported in literature for spices (Mepba and Nnoka, 2008; Khan and Choudry, 2010; Udofia and Alozie, 2015). The NDF values for Allium cepa, Allium sativum and Aframomum melegueta, Xylopia aethiopica were lower and higher respectively than the range of
$28.00-55.20 \%$ reported by Khan and Chaudhry (2010). The ADF values of Allium cepa, Allium cepa, Zingiber officinale were lower than $19.9-53.7 \%$ reported by Khan and Chaudhry (2010). The values for Aframomum melegueta and Xylopia aethiopica (Kaduna) were comparable with this range while the ADF value of Xylopia aethiopica (Enugu) was 


\section{Effect of some medicinal herbs and spices from Enugu and Kaduna States, Nigeria}

Table 5: Effect of location and medicinal herbs on in-vitro gas production and fermentation characteristics

\begin{tabular}{|c|c|c|c|c|c|c|c|c|c|c|c|c|}
\hline \multirow[b]{2}{*}{ VAR } & \multirow[b]{2}{*}{$\begin{array}{l}\text { LOC. } \\
\text { (L) }\end{array}$} & \multirow[b]{2}{*}{$\mathrm{ABA}$} & \multicolumn{6}{|c|}{ Herbs $(\mathrm{H})$} & \multirow[b]{2}{*}{ SEM } & \multicolumn{3}{|c|}{ Significance } \\
\hline & & & $\mathrm{ACO}$ & $\mathrm{CCI}$ & EHE & SAC & TPR & CTR & & $\mathrm{H}$ & $\mathrm{L}$ & $\mathrm{H}^{*} \mathrm{~L}$ \\
\hline GV & $\begin{array}{l}\text { EN } \\
\text { KD } \\
\text { SEM }\end{array}$ & $\begin{array}{l}21.69^{\mathrm{a}} \mathrm{A} \\
29.90^{\mathrm{a}}{ }_{\mathrm{A}} \\
4.90\end{array}$ & $\begin{array}{l}17.59^{\mathrm{a}} \mathrm{A} \\
17.00^{\mathrm{a}} \mathrm{A} \\
3.70\end{array}$ & $\begin{array}{l}29.90^{\mathrm{a}} \mathrm{A} \\
25.21^{\mathrm{a}} \mathrm{A} \\
2.33\end{array}$ & $\begin{array}{l}29.31^{\mathrm{a}} \mathrm{A} \\
23.45^{\mathrm{a}} \mathrm{A} \\
4.40\end{array}$ & $\begin{array}{l}21.69^{\mathrm{a}}{ }_{\mathrm{A}} \\
26.38^{\mathrm{a}}{ }_{\mathrm{A}} \\
2.86\end{array}$ & $\begin{array}{l}21.69^{\mathrm{a}} \mathrm{A} \\
28.14^{\mathrm{a}} \mathrm{A} \\
2.94\end{array}$ & $\begin{array}{c}30.48^{\mathrm{a}} \mathrm{A} \\
28.73^{\mathrm{a}} \mathrm{A} \\
3.33\end{array}$ & $\begin{array}{l}1.67 \\
2.18\end{array}$ & + & + & + \\
\hline DMDg & $\begin{array}{l}\text { EN } \\
\text { KD } \\
\text { SEM }\end{array}$ & $\begin{array}{l}630.00^{\mathrm{a}} \mathrm{A} \\
532.75^{\mathrm{a}} \mathrm{A} \\
37.77\end{array}$ & $\begin{array}{l}535.25^{\mathrm{a}} \mathrm{A} \\
567.00^{\mathrm{a}} \mathrm{A} \\
33.19\end{array}$ & $\begin{array}{l}631.75^{\mathrm{a}} \mathrm{A} \\
657.25^{\mathrm{a}} \mathrm{A} \\
42.32\end{array}$ & $\begin{array}{l}687.50^{\mathrm{a}} \mathrm{A} \\
654.50^{\mathrm{a}} \mathrm{A} \\
60.76\end{array}$ & $\begin{array}{l}571.00^{\mathrm{a}} \mathrm{A} \\
525.50^{\mathrm{a}} \mathrm{A} \\
20.45\end{array}$ & $\begin{array}{l}583.25^{\mathrm{a}} \mathrm{A} \\
626.50^{\mathrm{a}} \mathrm{A} \\
30.09\end{array}$ & $\begin{array}{c}635.17^{\mathrm{a}}{ }_{\mathrm{A}} \\
614.00^{\mathrm{a}}{ }_{\mathrm{A}} \\
39.77\end{array}$ & $\begin{array}{l}22.23 \\
19.97\end{array}$ & + & + & + \\
\hline $\mathrm{GVg}$ & $\begin{array}{l}\text { EN } \\
\text { KD } \\
\text { SEM }\end{array}$ & $\begin{array}{l}108.45^{\mathrm{a}} \mathrm{A} \\
149.49^{\mathrm{a}} \mathrm{A} \\
24.52\end{array}$ & $\begin{array}{l}87.94^{\mathrm{a}} \mathrm{A} \\
85.00^{\mathrm{a}} \mathrm{A} \\
18.51\end{array}$ & $\begin{array}{l}149.49^{\mathrm{a}} \mathrm{A} \\
126.04^{\mathrm{a}} \mathrm{A} \\
11.64\end{array}$ & $\begin{array}{l}145.56^{\mathrm{a}} \mathrm{A} \\
117.25^{\mathrm{a}} \mathrm{A} \\
22.02^{2}\end{array}$ & $\begin{array}{l}108.45^{\mathrm{a}} \mathrm{A} \\
131.90^{\mathrm{a}} \mathrm{A} \\
14.29\end{array}$ & $\begin{array}{l}108.45^{\mathrm{a}} \mathrm{A} \\
140.70^{\mathrm{a}} \mathrm{A} \\
14.72\end{array}$ & $\begin{array}{c}152.42^{\mathrm{a}}{ }_{\mathrm{A}} \\
143.63^{\mathrm{a}}{ }_{\mathrm{A}} \\
16.63\end{array}$ & $\begin{array}{l}8.33 \\
10.91\end{array}$ & + & + & + \\
\hline $\mathrm{CH}_{4} \mathrm{~g}$ & $\begin{array}{l}\text { EN } \\
\text { KD } \\
\text { SEM }\end{array}$ & $\begin{array}{l}70.35^{\mathrm{a}} \mathrm{A} \\
90.87^{\mathrm{ab}} \mathrm{A} \\
12.16\end{array}$ & $\begin{array}{l}61.55^{\mathrm{a}} \mathrm{A} \\
52.76^{\mathrm{b}} \mathrm{A} \\
12.32\end{array}$ & $\begin{array}{l}85.00^{\mathrm{a}} \mathrm{A} \\
73.28^{\mathrm{ab}} \mathrm{A} \\
9.87\end{array}$ & $\begin{array}{l}93.80^{\mathrm{a}}{ }_{\mathrm{A}} \\
70.35^{\mathrm{ab}} \mathrm{A} \\
13.82^{2}\end{array}$ & $\begin{array}{l}64.49^{\mathrm{a}} \mathrm{A} \\
70.35^{\mathrm{ab}} \mathrm{A} \\
7.05\end{array}$ & $\begin{array}{l}76.21^{\mathrm{a}} \mathrm{A} \\
85.00^{\mathrm{ab}} \mathrm{A} \\
15.10^{0}\end{array}$ & $\begin{array}{c}91.84^{\mathrm{a}} \mathrm{A} \\
76.29^{\mathrm{a}} \mathrm{A} \\
7.30\end{array}$ & $\begin{array}{l}5.26 \\
6.73\end{array}$ & + & + & + \\
\hline $\mathrm{CH}_{4} \mathrm{p}$ & $\begin{array}{l}\text { EN } \\
\text { KD } \\
\text { SEM }\end{array}$ & $\begin{array}{l}63.54^{\mathrm{a}} \mathrm{A} \\
66.49^{\mathrm{a}} \mathrm{A} \\
5.73\end{array}$ & $\begin{array}{l}72.08^{\mathrm{a}} \mathrm{A} \\
61.67^{\mathrm{a}} \mathrm{A} \\
5.01\end{array}$ & $\begin{array}{l}56.25^{\mathrm{a}} \mathrm{A} \\
58.21^{\mathrm{a}} \mathrm{A} \\
4.19\end{array}$ & $\begin{array}{l}64.30^{\mathrm{a}} \mathrm{A} \\
58.59^{\mathrm{a}} \mathrm{A} \\
4.20\end{array}$ & $\begin{array}{l}62.50^{\mathrm{a}} \mathrm{A} \\
52.92^{\mathrm{a}} \mathrm{A} \\
3.81\end{array}$ & $\begin{array}{l}71.55^{\mathrm{a}} \mathrm{A} \\
59.17^{\mathrm{a}} \mathrm{A} \\
9.42\end{array}$ & $\begin{array}{c}61.96^{\mathrm{a}} \mathrm{A} \\
76.29^{\mathrm{a}} \mathrm{A} \\
3.32\end{array}$ & $\begin{array}{l}2.62 \\
3.07\end{array}$ & + & + & + \\
\hline $\mathrm{CH}_{4} \mathrm{r}$ & $\begin{array}{l}\text { EN } \\
\text { KD } \\
\text { SEM }\end{array}$ & $\begin{array}{l}4.18^{\mathrm{a}}{ }_{\mathrm{A}} \\
2.58^{\mathrm{a}}{ }_{\mathrm{A}} \\
8.97\end{array}$ & $\begin{array}{l}-6.90^{\mathrm{a}} \mathrm{A} \\
8.65^{\mathrm{a}} \mathrm{A} \\
7.33\end{array}$ & $\begin{array}{l}16.02^{\mathrm{a}} \mathrm{A} \\
13.07^{\mathrm{a}} \mathrm{A} \\
8.19\end{array}$ & $\begin{array}{l}4.55^{\mathrm{a}} \mathrm{A} \\
12.45^{\mathrm{a}} \mathrm{A} \\
7.07\end{array}$ & $\begin{array}{l}7.94^{\mathrm{a}} \mathrm{A} \\
20.88^{\mathrm{a}} \mathrm{A} \\
5.44\end{array}$ & $\begin{array}{l}-6.50^{\mathrm{a}} \mathrm{A} \\
12.05^{\mathrm{a}} \mathrm{A} \\
13.94\end{array}$ & $\begin{array}{l}0.00^{\mathrm{a}} \mathrm{A} \\
0.00^{\mathrm{a}} \mathrm{A} \\
0.00\end{array}$ & $\begin{array}{l}3.99 \\
4.43\end{array}$ & + & + & + \\
\hline FE & $\begin{array}{l}\text { EN } \\
\text { KD } \\
\text { SEM }\end{array}$ & $\begin{array}{l}6.19^{\mathrm{a}}{ }_{\mathrm{A}} \\
4.64^{\mathrm{a}}{ }_{\mathrm{A}} \\
1.02\end{array}$ & $\begin{array}{l}7.54^{\mathrm{a}}{ }_{\mathrm{A}} \\
8.12^{\mathrm{a}}{ }_{\mathrm{A}} \\
1.69\end{array}$ & $\begin{array}{l}4.29^{\mathrm{a}}{ }_{\mathrm{A}} \\
5.49^{\mathrm{a}} \mathrm{A} \\
0.52\end{array}$ & $\begin{array}{l}4.97^{\mathrm{a}}{ }_{\mathrm{A}} \\
6.94^{\mathrm{a}} \mathrm{A} \\
1.21\end{array}$ & $\begin{array}{l}5.90^{\mathrm{a}}{ }_{\mathrm{A}} \\
4.23^{\mathrm{a}}{ }_{\mathrm{A}} \\
0.86\end{array}$ & $\begin{array}{l}6.11^{\mathrm{a}}{ }_{\mathrm{A}} \\
4.62^{\mathrm{a}} \mathrm{A} \\
0.86\end{array}$ & $\begin{array}{l}4.39^{\mathrm{a}}{ }_{\mathrm{A}} \\
4.64^{\mathrm{a}} \mathrm{A} \\
0.46\end{array}$ & $\begin{array}{l}0.46 \\
0.60\end{array}$ & + & + & + \\
\hline OMD & $\begin{array}{l}\text { EN } \\
\text { KD } \\
\text { SEM }\end{array}$ & $\begin{array}{l}49.96^{\mathrm{a}} \mathrm{A} \\
57.18^{\mathrm{a}} \mathrm{A} \\
4.32\end{array}$ & $\begin{array}{l}46.35^{\mathrm{a}} \mathrm{A} \\
45.83^{\mathrm{a}} \mathrm{A} \\
3.26\end{array}$ & $\begin{array}{l}57.18^{\mathrm{a}} \mathrm{A} \\
53.06^{\mathrm{a}} \mathrm{A} \\
2.05\end{array}$ & $\begin{array}{l}56.67^{\mathrm{a}} \mathrm{A} \\
51.51^{\mathrm{a}} \mathrm{A} \\
3.88\end{array}$ & $\begin{array}{l}49.96^{\mathrm{a}} \mathrm{A} \\
54.09^{\mathrm{a}} \mathrm{A} \\
2.52\end{array}$ & $\begin{array}{l}49.96^{\mathrm{a}} \mathrm{A} \\
55.64^{\mathrm{a}} \mathrm{A} \\
2.59\end{array}$ & $\begin{array}{c}57.70^{\mathrm{a}} \mathrm{A} \\
56.15^{\mathrm{a}} \mathrm{A} \\
2.93\end{array}$ & $\begin{array}{l}1.47 \\
1.92\end{array}$ & + & + & + \\
\hline SCFA & $\begin{array}{l}\text { EN } \\
\text { KD } \\
\text { SEM }\end{array}$ & $\begin{array}{l}0.46^{\mathrm{a}}{ }_{\mathrm{A}} \\
0.65^{\mathrm{a}}{ }_{\mathrm{A}} \\
0.12\end{array}$ & $\begin{array}{l}0.36^{\mathrm{a}}{ }_{\mathrm{A}} \\
0.35^{\mathrm{a}} \mathrm{A} \\
0.09\end{array}$ & $\begin{array}{l}0.66^{\mathrm{a}}{ }_{\mathrm{A}} \\
0.54^{\mathrm{a}}{ }_{\mathrm{A}} \\
0.06\end{array}$ & $\begin{array}{l}0.64^{\mathrm{a}}{ }_{\mathrm{A}} \\
0.50^{\mathrm{a}}{ }_{\mathrm{A}} \\
0.11\end{array}$ & $\begin{array}{l}0.46^{\mathrm{a}} \mathrm{A} \\
0.57^{\mathrm{a}}{ }_{\mathrm{A}} \\
0.07\end{array}$ & $\begin{array}{l}0.46^{\mathrm{a}}{ }_{\mathrm{A}} \\
0.61^{\mathrm{a}} \mathrm{A} \\
0.07\end{array}$ & $\begin{array}{l}0.67^{\mathrm{a}}{ }_{\mathrm{A}} \\
0.63^{\mathrm{a}}{ }_{\mathrm{A}} \\
0.08\end{array}$ & $\begin{array}{l}0.04 \\
0.05\end{array}$ & + & + & + \\
\hline $\mathrm{ME}$ & $\begin{array}{l}\text { EN } \\
\text { KD } \\
\text { SEM }\end{array}$ & $\begin{array}{l}5.82^{\mathrm{a}}{ }_{\mathrm{A}} \\
6.93^{\mathrm{a}}{ }_{\mathrm{A}} \\
0.67\end{array}$ & $\begin{array}{l}5.26^{\mathrm{a}}{ }_{\mathrm{A}} \\
5.18^{\mathrm{a}}{ }_{\mathrm{A}} \\
0.50\end{array}$ & $\begin{array}{l}6.93^{\mathrm{a}}{ }_{\mathrm{A}} \\
6.30^{\mathrm{a}}{ }_{\mathrm{A}} \\
0.32\end{array}$ & $\begin{array}{l}6.85^{\mathrm{a}}{ }_{\mathrm{A}} \\
6.05^{\mathrm{a}} \mathrm{A} \\
0.60\end{array}$ & $\begin{array}{l}5.81^{\mathrm{a}} \mathrm{A} \\
6.46^{\mathrm{a}}{ }_{\mathrm{A}} \\
0.39 \\
\end{array}$ & $\begin{array}{l}5.82^{\mathrm{a}}{ }_{\mathrm{A}} \\
6.69^{\mathrm{a}} \mathrm{A} \\
0.40\end{array}$ & $\begin{array}{l}7.01^{\mathrm{a}}{ }_{\mathrm{A}} \\
6.77^{\mathrm{a}} \mathrm{A} \\
0.45 \\
\end{array}$ & $\begin{array}{l}0.23 \\
0.30\end{array}$ & + & + & + \\
\hline
\end{tabular}

higher. The ash values obtained from the spices were comparable with what was reported by Udofia and Alozie (2015).

The variations observed in the chemical composition of the experimental plant part(s) collected from Enugu and Kaduna states could be due to several factors which include plant species, part, leaf age, fertilizer application and others which vary with locations such as soil type, climate and rainfall (Ball et al., 2001; Njidda, 2010; Midau et al., 2015). The CP content of most of the herbs and spices collected from Kaduna were higher than their Enugu counterparts. This observation is in agreement with the reports by Rittner and Reed (1992) that plants in the Sahelian zone have higher nitrogen content than those found in the humid zone. Most of the herbs and spices in this study had CP values above the minimum protein requirement of $10-12$ $\%$ recommended for ruminant livestock by ARC (1985) suggesting that they could be useful in meeting the dietary $\mathrm{CP}$ 


\section{Iyere, Bamikole, Ikhatua, Babayemi and Egigba}

requirement of ruminant livestock. There were variable effects of location and plant species on the fiber content of the plant samples collected. The fiber content of plants is dependent on synergy between factors such as plant developmental stage, leaf to stem ratio, nutrient availability and climatic factors such as temperature, photoperiod and drought or water stress (Fulkerson et al., 2007). NDF gives an indication of the level of voluntary intake of forages. Thus as the NDF level increases, the voluntary intake is expected to decline (Coblentz and Hoffman, 2008). High temperature results in higher forage content of NDF and reduced fiber digestibility. The increase in temperature leads to increased microbial respiration. This in turn results in a rise in the level of NDF, ADF and lignin in plant tissues due to microbial oxidation of soluble sugars (Coblentz and Hoffman, 2008). Bakshi and Wadhwa (2004) stated that beyond $60 \% \mathrm{NDF}$ content of forage, voluntary DM intake is negatively affected. For Enugu alone Sida acuta only exceeded this limit while there was no plant for Kaduna only. While plants from both locations that exceeded the limit are Aframomum melegueta, Xylopia aethiopica and Cymbopogon citratus. The implication is that when these plants are to be included in ruminant diet techniques to improve their digestibility will also have to be considered. The level of ADF gives an indication of the digestibility and energy content of plant material. It has been established that the energy level of forages declines as the ADF level increases. Shroeder (2004) states that as the ADF content increases, forage digestibility decreases. The decrease in digestibility with increased ADF content was suggested to be due to the increased concentration of lignin. Van Soest (1967) also stated that as NDF level increases there is a decrease in the utilization of fiber. Hemicellulose content may also give an indication of how digestible forages are due to the fact that it may be highly digestible provided that it has not being lignified. Ball et al. (2007) classified forages with ADF values greater than $43.00-45.00 \%$ as low quality forages. This is attributed to the fact that forages with higher ADF levels are expected to have lower digestibilities due to the aforementioned reasons.

Thus, the fiber components of forages may not be used in insolation from one another in accessing forage quality due to their individual significance. With these limits suggested from literature, the plant samples in this study may be classified on the basis of voluntary DM intake and digestibility by ruminant livestock into those that are expected to decline in one or both of the indices of forage quality. Thus, Cymbopogon citratus (Enugu), Aframomum melegueta and Xylopia aethiopica (both locations) may be classified as those with expected decrease in DM intake and digestibility. While Cymbopogon citratus (Kaduna) may be characterised with reduced voluntary DM intake by ruminant livestock. Allium cepa and Allium sativum were characterised with very low levels of fiber (NDF and ADF) which would necessitate a good fiber source with their inclusion in the diet of ruminant livestock. Significantly lowered GV with Zingiber offinale and Allium sativum has been reported (Bunglavan et al., 2010) at $50 \mathrm{mg} / 500 \mathrm{mg}$ substrate. Conversely, higher $\mathrm{GV}$ with spice inclusion have been reported by several authors. Soroor and Moeini (2015) reported increased GV with Zingiber officinale at higher inclusion levels $(30,60 \mathrm{mg} / 200 \mathrm{mg}$ substrate). Extracts of ginger have also been reported to increase GV (Patra, 2010 and Kim et al., 2012). Sallam et al. (2009) reported increased $\mathrm{GV}$ with methanol extracts $(0.5,1.0$ and $1.5 \mathrm{~mL} / 75 \mathrm{~mL})$ of thyme, fennel, ginger and black seed. However, ginger and black seed at the 


\section{Effect of some medicinal herbs and spices from Enugu and Kaduna States, Nigeria}

highest inclusion level $(1.5 \mathrm{~mL} / 75 \mathrm{~mL})$ decreased $\mathrm{GV}$ by 4.6 and $22.5 \%$ respectively. These reports on various spice treatments are at variance with the observations in this study.

There are reports of varying DMD and OMD responses due to inclusion of spices as was observed in this study. Sirohi et al. (2012) reported DMD response with spice extract inclusion $(1 \mathrm{~mL} / 30 \mathrm{~mL}$ ruminal fluid) in-vitro. It was observed that methanol extracts of green chilli and Myristica fragrans increased and reduced DMD respectively. Increased OMD due to inclusion of ginger (Soroor and Moeini, 2015; Patra, 2010) and decreased OMD with methanol extracts of ginger and black seed at $1.5 \mathrm{~mL} / 75 \mathrm{~mL}$ (Sallam et al., 2009) has been reported. The Highest $\mathrm{CH}_{4}$ reduction in this study is comparable to what was reported $(21.00 \%)$ at $30 \mathrm{mg} / 200$ $\mathrm{mg}$ by Soroor and Moeini (2015) for Zingiber officinale. It is however lower than what was reported (62.04 \%) for Myristica fragrans methanol extract (Sirohi et al., 2012). However, the increase in $\mathrm{CH}_{4}$ production observed in Aframomum melegueta (Kaduna) is not uncommon as Sallam et al. (2009) reported increased $\mathrm{CH}_{4}$ production (55-166\%) with inclusion of spice extracts. Kim et al. (2012) reported no significant effect of the inclusion of methanol extracts of Allium sativum, Allium cepa and Zingiber officinale on SCFA concentration in-vitro at inclusion level of $0.3 \mathrm{~mL} / 30 \mathrm{~mL}$ buffered rumen fluid. The values for $\mathrm{FE}$ due to spice inclusion were higher than the theoretical range of $2.75-$ 4.41 proposed by Blummel et al. (1997). Getachew et al. (2000) reported an FE range of 3.1 to 16.1 for feeds rich in tannin. Zingiber officinale and Aframomum melegueta have been reported to contain EO, tannins, saponins, flavonoids and terepenes (Jude and Nneka, 2012; Bhargava et al., 2012). Allium sativum and Xylopia aethiopica have been reported to contain EO, with the former also containing saponins while tannins and saponins are present in the latter (Ameh et al., 2013; Omeh et al., 2014; Adesina et al., 2015). Gazuwa et al. (2013) reported that Allium cepa contains terpenes, flavonoids and alkaloids. These reports indicate the presence of EO and other PSM in spices. Hence the inhibition of methanogenesis may be attributed to presence of one or more of the PSM in the spices of the current study.

Ageratum conyzoides, Sida acuta, Tridax procumbens and Aloe barbadense have been reported to contain tannin and saponins (Jude et al., 2009; Adesuyi et al., 2012; Agunbiade et al., 2012; Rami et al., 2014; Nduche et al., 2015) while for Euphorbia heterophylla, saponins were not reported (Edeoga et al., 2005; James and Emmanuel, 2010). Cymbopogon citratus is reported to contain EO and alkaloids (OgieOdia et al., 2010; Salome et al., 2012; Ekpenyong et al., 2015; Uraku, 2015). Hence the reduction in $\mathrm{CH}_{4}$ production by the herb treatments may be due to the presence of tannins and/or saponins or EO in the herbs. Tannins and saponins have been reported to reduce methanogenesis by inhibiting protozoa (indirect effect) and methanogens (Patra and Saxena, 2009; Mao et al., 2010; Patra, 2012). Significantly reduced digestibility, SCFA and GV have been attributed to the presence of tannin and saponin extracts respectively in-vitro (Santoso et al., 2007; Patra2010; Tan et al., 2011). The fact that these effects were not observed significantly in this study may be related to their concentration. SzumacherStrabel et al. (2011) suggested that the low effect of tannin containing feed additives in-vitro may be due to their low concentration in the additives.

The source, type and level of tannins and saponins may be responsible for the different levels of inhibition of methane 


\section{Iyere, Bamikole, Ikhatua, Babayemi and Egigba}

production and rumen fermentation associated with some medicinal plants (Mueller-Harvey, 2006; Gugliemelli et al., 2011; Jayanegara et al., 2014). Hence increasing the inclusion level of the additives may result in significant effects being observed. These herbs have the potential for improved DMD and other favourable responses in vivo although their effects were not significant in the present study. Wanapat et al. (2008) reported that lemon grass powder supplementation at $100 \mathrm{~g} /$ day DM to a basal diet of urea treated rice straw improved nutrient digestibility, rumen microbial population and microbial protein synthesis in beef cattle. Reduction in the quantity of $\mathrm{CH}_{4}$ produced is a most desired characteristic of plant additives and forages which should not be at the detriment of desired fermentation parameters such as improved DMD, OMD, FE, SCFA and ME. From both locations Allium sativum, Zingiber officinale, Cymbopogon citratus and Sida acuta gave the highest $\mathrm{CH}_{4}$ reductions without significant decline in the desired fermentation parameters in contrast with the control indicating that they have the potential of being able to safely mitigate $\mathrm{CH}_{4}$ production in ruminant livestock.

\section{Conclusion}

Generally, Allium sativum bulbs, Zingiber officinale rhizome, Cymbopogon citratus and Sida acuta from both Enugu and Kaduna have shown potential for reducing ruminal methane production in vitro. The potential demonstrated was without compromising the desired fermentation parameters. The ability of these plants to sustain the reduction of rumen methane production in vivo should be considered for further study.

\section{References}

Adesina, J.M., Jose, A.R., Rajashaker, Y and Afolabi, L.A., 2015.
Entomotoxicity of Xylopia aethiopica and Aframomum melegueta in suppressing oviposition and adult emergence of Callosobruchus maculatus (Fabricus) (Coleoptera: Chrysomelidae) infesting stored cowpea seeds. Jordan Journal of Biological Science, 8(4), 263 -268

Adesuyi, A.O., Awosanya, O.A., Adaramola, F.B. Omeonu, A.I., 2012 . Nutritional and phytochemical screening of Aloe barbadensis. Current Research Journal of Biological Science 4, 4-9

Adu, O.B., Folorunso, O.S., Adeola, S.A and Godfrey, C., 2013. Antioxidant and Antimicrobial properties of volatile oil of Terminalia catappa and its inhibition on the extracellular protease of Pseudomonas aeruginosa. Research Journal of Life Science 1(1), 1-8

Agunbiade, O.S., Ojezele, O.M., Ojezele, J.O. and Ajayi, A.Y., 2012. Hypoglycaemic activity of Commelina africana and Ageratum conyzoides in relation to their mineral composition. African Health Science.12(2), 198-202.

Ahamefule, F.O., Obua, B.E., Ibeawuchi, J.A. and Udosen, N.R., 2006. The nutritive value of some plants browsed by cattle in Umudike, Southeastern Nigeria. Pakistan Journal of Nutrition, 5 (5), 404409

Ajayi, F.T. and Babayemi, O.J., 2008. Comparative in vitro evaluation of mixtures of $P$ a $n$ i c $c u$ m maximum cv Ntchisi with stylo (Stylosanthes guianensis), Lablab (Lablab purpureus), Centro (Centrosema pubescens) and 


\section{Effect of some medicinal herbs and spices from Enugu and Kaduna States, Nigeria}

Histrix (Aeschynomene histrix). Livestock Research for Rural Developmet, 20 ( 6 ). http://www.lrrd.org/lrrd20/6/ajay 20083.htm

Ameh, G.I, Eze, S.C. and Omeje, F.U., 2013. Phytochemical screening and antimicrobial studies on the methanolic bulb extract of Allium sativum. African Journal of Biotechnology. 12(4), 1665-1668.

AOAC, 2000. Official Methods of Analysis, 17 th edition. Association of Official Analytical Chemists, Washington DC, USA.

ARC, 1980. Agricultural Research Council. The nutrient requirements of ruminant livestock. (CAB, Farnham Royal, U.K.)

ARC, 1985. Agricultural Research Council. The nutrient requirements of farm animals, No 2, Ruminants: Technical Review of summaries (ARC, London)

Babayemi, O.J., 2009. Silage quality, dry matter intake and digestibility by West African dwarf sheep of Guinea grass (Panicum maximum cv Ntchisi) harvested at 4 and 12 weeks of regrowths. African Journal of Biotechnology ,8(16), 3983-3988.

Bakshi, M. P. S. and Wadhwa, M. 2004. Evaluation of forest leaves of semi-hilly arid region a $\mathrm{s}$ livestock feed. AsianAustralasian. Journal of Animal Science. 95, 93-104.

Ball, D., Collins, M., Lacefield, G., Martin, N., Mertens, D., Olson, K., Putman, D., Undersander, D. and Wolf, M., 2001 . Understanding Forage Quality. (American Farm Bureau Federation Publication, Park Ridge). 1-17 pp.
Ball, D. M., Hoveland, C. S. and Lacefield, G. D., 2007. Southern Forages. 4th ed. (Potash and Phosphate Institute and Foundation for Agronomic Research. Norcross, GA)

Bamikole, M.A. and Babayemi, O.J., 2004. Feeding goats Guinea grass-Verano-Stylo and Nitrogen fertilized grass with energy concentrate. Archivos de Zootecnia, 53 (201),77pp.

Belewu, M. A, Olatunde, O.A. and Giwa, T. A., 2009. Underutilized medicinal plants and spices: Chemical composition and phytochemical properties. Journal of Medicinal Plants Research.3(12), 1099-1103.

Bhargava, S., Dhabbai, K., Batra, A., Sharma, A. and Malhorta, B., 2012. Zingiber Officinale: Chemical and phytochemical screening and evaluation of its antimicrobial activities. Journal of Chemical and Pharmaceutical Research. 4(1),360-364.

Blummel, M., Makkar, H. P. S. and Becker, K., 1997. In vitro gas production: a technique Revisited. Journal of Animal Physiology and Animal Nutrition. 77, 24-34.

B u n g l a va n, S . J ., Val li, C ., Ramachandran, M. and Balakrishnan, V., 2010. Effect of supplementation of herbal extracts on methanogenesis in ruminants. Livestock Research for Rural Development. 22 (11).

Coblentz, W. and Hoffman, P., 2008. Heat damaged forages: effects on forage quality. Focus on forage. $10(8): 1-4$.

Doherty, V.F., Olaniran, O.O. and K a n i f e, U . C ., 2010 . Antimicrobial ativities of 


\section{Iyere, Bamikole, Ikhatua, Babayemi and Egigba}

Aframomum melegueta. International Journal of Biology. 2(2), $126-129$.

Eckard, R.J., Grainger, C. and De Klain, C.A.M., 2010. Options for abatement of methane and nitrous oxide from ruminant production: A review: Livestock Science. 130, 48-49.

Edeoga, H.O., Okwu, D.E. and Mbaebie, B.O., 2005. Phytochemical constituents of some Nigerian medicinal plants. African Journal of Biotechnology. 4 (7), 685-688.

Ekpenyong, C.E., Daniel, N.E. and Antai, A.B., 2015. Bioactive natural constituents from lemon grass tea and erythropoiesis boosting effects: potential use in prevention and treatment of anaemia. Journal of Medicinal. Food. 18(1), 118 127.

Fievez, V., Babayemi, O. and Demeyer, D., 2005. Estimation of direct and indirect gas production in syringes: A tool to estimate short chain fatty acid production that requires minimal laboratory facilities. Animal Feed Science Technology. 123, 197-210.

FAO. 2006. Food and Agriculture Organisation. Livestock's Long shadow. (Environmental Issues and options. FAO. Rome). http://www.fao.org/docrep/010/a 0701e00.htm

FAO., 2010. Food and Agriculture Organisation. The Impact of animal agriculture on the environment and climate change in India: A Focus on methane. HIS Fact Sheet. Hamane Society International.

Forster, P., Ramaswany, V., Artaxo, P., Bernsten, T., Betts, R., Fahey, D.W., Haywood, J., Lean, J., Lowe, D.C., Myhre, G., Nganga,
J., Prinn, R., Raga,G., Shulz, M. and Van Dorland, R., 2007. Changes in atmospheric constituents and in radiative forcing. In: Climate change 2007: The Physical Science Basis. Contribution of working Group I to fourth assessment report of the Intergovernmental Panel on Climate Change. Cambridge University Press, United Kingdom.

Fulkerson, W.J., Neal, J.S., Clark, C.F., Horadagoda, A., Nandra, K.S., Barchia, I., 2007. Nutritive value of forage species grown in the warm temperate climate of Australia for dairy cows: Grasses and legumes. Livestock Science. 107, 253-264.

Garba, S. and Okeniyi, S.O., 2012. Antimicrobial activities of total alkaloids extracted from some Nigerian medicinal plants. Journal of Microbiology. Antimicrobials. 4(3), 60-63

Gazuwa, S.Y., Makanjuola, E.R., Jaryum, K.H., Kutshik, J.R. and Mafulul, S.G., 2013. The Phytochemical Composition of Allium cepa/Allium sativum and the effects of their aqueous extracts (cooked and raw forms) on the lipid profile and other hepatic biochemical parameters in female albino wistar rats. Asian Journal of Experimental Biological Science. 4 (3), 406410.

Getachew, G., Makkar, H.P.S. and Becker, K., 1999. Stoichiometric relationship between short chain fatty acid and in vitro gas production in presence and absence of polyethylene glycol for tannin containing browses, EAAP Satellite 


\section{Effect of some medicinal herbs and spices from Enugu and Kaduna States, Nigeria}

symposium, Gas production: Fermentation kinetics for feed evaluation and to assess microbial activity. 18 - 19 August, Wageningen, The Netherlands.

Getachew, G., Makkar, H.P.S. and Becker, K., 2000. Tannins in tropical browses: effects of tannins on in vitro microbial fermentation and microbial protein synthesis in medium containing different amounts of nitrogen, Journal of Agriculture and Food Chemistry. 48: 3581 3588 .

Gillespie, J.R., 1998. Animal Science. (Delmar publishers international. Thompson Publishing Company). $1204 \mathrm{pp}$.

Guglielmelli, A., Calabro,S., Primi, R., Carone, F., Cutrignelli, M.I., Tudisco, R., Piccolo, G., Ronchi, B. and Danieli, P.P., 2011. In vitro fermentation patterns and methane production of sainfoin (Onobrychis viciifolia Scop.) hay with different condensed tannin contents. Grass Forage Science 66:488-500.

IPCC 2007. Intergovernmental Panel on Climate Change. The physical sciences basis group contribution to the Fourth Assessment of the IPCC. Cambridge University Press. 96 pp.

James, O. and Emmanuel, T.F., 2010. Phytochemical composition, bioactivity and wound healing potential of Euphorbia heterophylla (euphorbiaceae) leaf extract. International Journal of Pharmaceutical Biomedical Research.1(1), 54-63.

Jayanegara, A, Wina, E. and Takahashi, J., 2014. Meta-analysis on methane mitigating properties of saponin-rich Sources in the rumen: Influence of addition levels and plant sources. Asian Australasian Journal of Animal Science. 27(10): 14261435.

Jude, C.I, Ikewuchi, C., Catherine, M.I. and Ngozi, M.I., 2009. Chemical profile of Tridax procumbens $\mathrm{L}$. Pakistan Journals of Nutrition.8(5), 548-550.

Jude, U. A. and Nneka, V.C.,2012. Antimicrobial properties and phytochemical Analysis of methanolic extracts of Aframomum melegueta and Zingiber officinale on fungal diseases of tomato fruit. Journal of National Scientific Research.2 (6), 10-15.

Khan, M.M. and Chaudhry, A., 2010. Chemical composition of selected forages and spices and the effect of these spices in in vitro rumen degradability of some forages. Asian-Australasian. Journal of Animal Science. 23(7), 889-900.

Kim, E.T., Kim, C-H., Min, K.-S. and Lee, S.S., 2012. Effects of plant extracts on microbial population, methane emission and ruminal fermentation characteristics in vitro. Asian-Australasian Journal of Animal Science. 25 (6): 806-811.

Mao, H.L., Wang, J.K., Zhou, Y.Y. and Liu, J.X., 2010. Effects of addition of tea saponins and soyabean oil on methane production, fermentation and microbial population in the rumen of growing lambs. Livestock Science. 129: 56-62.

McDonald, P., Edwards, R.A., GreenHalgh, J.F.D. and Morgan, C.A., 1995. Animal Nutrition, $5^{\mathrm{TH}}$ Edition, (Longman, U.K.) 607 pp. 
Iyere, Bamikole, Ikhatua, Babayemi and Egigba

Menke, K. H., Raab, L., Salewski, A., Steingass, H., Fritz, D., Schneider, W., 1979. The estimation of the digestibility and metabolizable energy content of ruminant feedstuffs from the gas production when they are incubated with rumen liquor in vitro. Journal of Agricultural Science. 92, 217-222

Menke, K.H. and Steingass, H., 1988. Estimation of the energetic feed value obtained from chemical Analysis and in vitro gas production using rumen fluid. Animal Research Development. 28, 7-58.

Mepba, H.D. and Oguka- Nnoka, C.U., 2008. Proximate composition and antinutrient contents of some common spices in Nigeria. The Open Food Science Journal 2: 6267.

Midau, A., Mubi, A.A. and Uri, Z.Z., 2015. Evaluation of nutrient composition of selected forages in the livestock research farm of Adamawa State University. Journal of Animal Science Advances. 5(1): 1151-1156.

Mueller-Harvey, I., 2006. Unraveling the conundrum of tannins in animal nutrition and health. Journal of Science, Food and Agriculture. 86,2010-2037.

Nduche, M. U., Edeoga, H. O., Omosun, G. and Nwankwo, D., 2015. Evaluation of the Chemical composition of five Nigerian medicinal plants. IOSR Journal of Pharmacy and Biological Science. 10(2): 27-31.

Njidda, A.A., 2010. Chemical composition, fibre fraction and anti-nutritional substances of some semi-arid browse forages of North- Eastern Nigeria. Nigerian
Journal of Basic Applied Science .18(2), 181-188.

Norton, B.W., 1994. Tree legumes as dietary supplements for ruminants. In: Gutteridge, R.C. and H.M., Shelton (editors). Forage tree legumes in tropical agriculture, (CAB International) pp 192-201.

Ogie-odia, E.A., Esiegbe, D., Ilechie, M.N., Erhabor, J. and Ogbebor, E., 2010. Foliar epidermal and phytochemical studies of the grasses Cymbopogon citratus (stapf), Axonopus compressus (P. Beauv) and Eragrotis tremula (S. W. Beauv) in Ekpoma, Edo State, Nigeria. Scientific World Jurnal 5(1),20-25.

Omajasola, P. and Kayode, R.M., 2015. Microbial quality assessment and physio-chemical properties of selected poultry feeds from commercial feed mills in Ilorin, Nigeria. International Journal of Applied Agriculture and Apicultural Research. 11 (1 \& 2), 60-66pp.

Omeh, Y.N., Onoja, S.O., Ezeja, M.I., Bassey, S., Ogbenta, G. and Ad e tayo, A. B ., 2014 . Phytochemical, nutrient composition and serum lipid lowering effect of Xylopia aethiopica fruit. Br. Journal of Pharmaceutical Research. 4(17) 2096-2105.

Patra, A. K. and Saxena, J., 2009. Dietary phytochemicals as rumen modifiers: a review of the effects on microbial populations. Anton. Leeuwenhoek International Journal of Gen. M. 96:369-375.

Patra, A. K. 2010. Meta-analyses of effects of phytochemicals on digestibility and rumen fermentation characteristics associated with 


\section{Effect of some medicinal herbs and spices from Enugu and Kaduna States, Nigeria}

methanogenesis. Journal of Science, Food and Agriculture. 90, 2700-2708.

Patra, A. K. 2012. Dietary phytochemicals and Microbes. (Springer Science and Publishing). 343pp.

Rami, M. M., Oyekanmi, A. M. and Adegoke, B. M. 2014. Proximate, phytochemical and micronutrient composition of Sida acuta. Journal of Applied Chemistry. 7(2): 93-98

Rittner, U. and Reed, J. D. 1992. Phenolics and in vitro degradability of protein and fiber in West African browse. Journal of Science. Food and Agriculture. 58:21-28.

Sallam, S. M. A., Bueno, I.C.S., Brigide, P., Godoy, P.B., Vitti, D.M.S.S., A bd a Ila, A.L., 2009 . Investigation of potential new opportunities for plant extracts on rumen microbial fermentation in vitro. In : Papachristou T.G. (ed.), ParissiZ.M.(ed.), $\quad$ B e $n$ Salem H. (ed.), Morand-Fehr P. (ed.). Nutritional and foraging ecology of sheep and goats. Zaragoza: CIHEAM / FAO / NAGREF. O. SA. (85):255-260.

Salome, A. C., Emeka, C. U., Ikechukwu, V. O., Sinye, A. B., Callister, E. U. and Godswill, C. O., 2012. Formulation and evaluation of Cymbopogon citratus dried leafpowder tablets. African. Journal of Pharmacy and Pharmacology. 6(48): 3274-3279.

Santoso, B., Kilmaskossu, A. and Sambodoc, P., 2007. Effects of saponins from Biophytum petersianum Klotzsch on ruminal fermentation, microbial protein synthesis and $\mathrm{n}$ i t $\mathrm{r}$ o g e $\mathrm{n}$ utilization in goats. Animal Feed $S c i e n c e \quad a n d$ Technology.137,58-68.
Schroeder, J. W. 2004. Forage nutrition for ruminants. Quality Forage. North Dakota University Extension Services.1-14.

Seresinhe, T., Perera, A. N. F. and Lal, P. K., 2014. In vitro screening of some tropical goat feeds for low methane and high ammonia generating potential in the rumen. Livestock Research for Rural Development. 26, Article 52.http://www.lrrd.org/lrrd26/3/s ere26052.html

Sirohi, S.K., Goel, N. and Pandey. P., 2012. Efficacy of different methanolic plant extracts on anti-methanogenesis, rumen fermentation and gas production kinetics in vitro. Open Veterinary Journal. 2, $72-77$.

Soroor, M. E. N. and Moeini, M. M., 2015. The Influence of Ginger (Zingiber Officinale) on in vitro rumen fermentation patterns. Annual Research. Reviews in Biology. 5(1),54-63.

SAS, 2014. Statistical Analysis Systems. SAS-STAT Program. SAS Institute Inc.Cary, $\mathrm{N}$ o $\mathrm{r} \mathrm{th}$ Carolina:

Sultan, J. I., Inam-Ur- Rahimi, Yaqoob, M., Nawazi, H. and Akhtar, P., 2009. Nutritional evaluation of herbs as fodder source for ruminants. Pakistan Journal of Botany. 41(6), 2765-2776.

Szumacher-Strabel, M., Zmora, P., Roj, E., Stochmal, A, Pers-Kamczyc, E., Urbanczyk A, Oleszek, W., Lechniak, D. and Cieslak, A. 2011. In vitro screening of the wild dog rose (Rosa canina) potential to mitigate rumen methane production. Journal of Animal Feed Science.20, 285-299.

Tan, H. Y., Sieo, C. C., Abdullah, N., Liang, J. B., Huang, X. D. and 


\section{Iyere, Bamikole, Ikhatua, Babayemi and Egigba}

Ho, Y.W., $2011 . \quad$ Effects of condensed tannins from Leucaena on methane production, rumen fermentation and populations of methanogens and protozoa in vitro. Anim. Feed Science Technology. Amsterdam. 169: 185-193.

Tilley, J. M. A. and Terry, R. A., 1963. A two stage technique for the in vitro digestion of forage crops. $J$. Br. Grassl. Soc. 18: 104-111

Udofia, U. S. and Alozie, Y. E., 2015 . Nutrients and phytochemical composition of spices in relation to health: "Uyayak" (Tetrapleura tetraptera), "Odusa" (Piper guineense), "Inwun" (Monodora myristica) and "Ata" (Xylopia aethiopica). Nigerian Journal of Agriculture, Food and Environment. 11(2):211-214.

UNDESA. 2013. United Nations Department of Economic and Social Affairs, Population Division. World Population Prospects. The 2012 Revision, Key findings and advanced tables. Working paper. UN, New York. 15 p.

Uraku, A. J. 2015. Determination of chemical composition of Cymbopogon citratus leaves by gas Chromatography-Mass Spectrometry (GC-MS) Method. Res. J.Phytochem. 9:175187.
Uzeh, R. E. and Oguntosin, D. O. 2013.

Efficacy of essential oils from some african spices against two strains of Bacillus cereus isolated from vegetable salad. Journal of Food Research.2(6)

Van Soest, P. J. 1967. Development of a comprehensive system of feed a $n$ a 1 y s i s a $n$ d i $\mathrm{s}$ applications to forages. Journal of Animal. Science. 26: 119-128.

Van Soest, P. J. Robertson, J. B. and Lewis, B. A. 1991. Methods for dietary fiber, neutral detergent fiber and non-starch polysaccharides in relation to animal nutrition. Journal of Dairy Science., 74, 3583-3597.

Wanapat, M., Cherdthong, A., Pardee, P. and Wanapat, S. 2008 . Manipulation of rumen ecology by dietary lemongrass (Cymbopogon citratus Stapf.) powder supplementation. Journal of Animal Science. 86 , 3497-3503.

Received: $17^{\text {th }}$ October, 2018 Accepted: $20^{\text {th }}$ February, 2019 